\title{
Notch1 is essential for postimplantation development in mice
}

\author{
Pamela J. Swiatek, ${ }^{1}$ Claire E. Lindsell, ${ }^{2}$ Francisco Franco del Amo, ${ }^{1,3}$ Gerry Weinmaster, ${ }^{2}$ and \\ Thomas Gridley ${ }^{1,4}$ \\ ${ }^{1}$ Roche Institute of Molecular Biology, Roche Research Center, Nutley, New Jersey 07110 USA, ${ }^{2}$ Department of Biological \\ Chemistry, School of Medicine, University of California, Los Angeles, California 90024 USA
}

The Notch gene of Drosophila encodes a large transmembrane protein involved in cell fate determination during embryonic and larval development. This gene is evolutionarily conserved, and Notch homologs have been cloned from several vertebrate species. To examine the in vivo role of the Notch1 gene, a mouse homolog of Notch, a mutation was introduced by targeted disruption in embryonic stem cells, and these cells were used to generate mutant mice. Intercrosses of animals heterozygous for the Notch1 mutation yielded no live-born homozygous mutant offspring. Homozygous mutant embryos died before 11.5 days of gestation. Morphological and histological analysis of the homozygous mutant embryos indicated that pattern formation through the first nine days of gestation appeared largely normal. However, histological analysis of mutant embryos subsequent to this stage revealed widespread cell death. Death of mutant embryos did not appear to be attributable to defects in placentation or vascularization. Examination of the RNA expression pattern of the Notch2 gene, another Notch gene family member, indicated that it partially overlapped the Notch1 expression pattern. Genetic analysis of the Notch1 mutation also demonstrated that it was not allelic to a mouse mutation described previously, Danforth's short tail $(S d)$. These results demonstrate that the Notch1 gene plays a vital role during early postimplantation development in mice.

[Key Words: Notch; neurogenic genes; Danforth's short tail; Sd]

Received November 15, 1993; revised version accepted January 20, 1994.

The Notch locus in Drosophila encodes a large transmembrane protein required for proper epidermal versus neural cell fate decisions in the neurogenic region of the ectoderm (for review, see Greenspan 1990; ArtavanisTsakonas et al. 1991; Campos-Ortega and Jan 1991; Greenwald and Rubin 1992). In embryos homozygous for null mutations of the Notch gene, essentially all cells in the neurogenic region become neuroblasts. Such embryos die with a vast hypertrophy of the nervous system and a corresponding absence of epidermal structures. Embryos homozygous for null mutations of at least five other zygotically acting loci, termed the neurogenic genes, exhibit a similar mutant phenotype.

The Notch protein contains several repeated amino acid motifs. The extracellular domain contains 36 tandemly repeated copies of an epidermal growth factor (EGF)-like sequence (Wharton et al. 1985; Kidd et al. 1986), as well as three repeats of another cysteine-rich motif, termed the Notch/lin-12 repeat. This motif is found in the proteins encoded by the Notch gene as well as by two genes in Caenorhabditis elegans, lin-12, and glp-1 (Yochem and Greenwald 1989). The intracellular

\footnotetext{
${ }^{3}$ Present address: Departamento de Bioquimica e Bioloxia Molecular, Facultade de Bioloxia, Universidade de Santiago de Compostela, Spain. ${ }^{4}$ Corresponding author.
}

domains of Notch, as well as lin-12 and glp-1, also contain six copies of another amino acid motif termed the $c d c 10 /$ ankyrin repeats. This motif was first identified in several genes involved in cell cycle regulation in yeast (Aves et al. 1985; Breeden and Nasmyth 1987; Andrews and Herskowitz 1989) and has since been found in ankyrin and a wide variety of other proteins (Davis and Bennett 1990; Lux et al. 1990; Ohno et al. 1990; Spence et al. 1990; Thompson et al. 1991). This motif has been shown recently to be involved in protein-protein interactions (Davis and Bennett 1990; Thompson et al. 1991).

Recent work has shown that many genes involved in the control of important developmental events in Drosophila are conserved in vertebrates. Notch homologs have been cloned from several vertebrate species, and amino acid sequence analysis has permitted the assignment of the vertebrate Notch genes to distinct groups (Weinmaster et al. 1992). Genes of the Notch1 family have been cloned from Xenopus (Coffman et al. 1990), man (Ellisen et al. 1991), rat (Weinmaster et al. 1991), and mouse (Franco del Amo et al. 1992, 1993; Reaume et al. 1992; Kopan and Weintraub 1993; Lardelli and Lendahl 1993). Recently, Weinmaster et al. (1992) described the sequence and expression pattern of a rat cDNA clone encoding a second Notch homolog, Notch2. Partial cDNA clones encoding Notch2 genes have also been isolated 
from humans (Stifani et al. 1992) and mice (Lardelli and Lendahl 1993; F.F. del Amo and T. Gridley, unpubl.). A third, more distantly related member of the Notch gene family is the int-3 gene, a common integration site for mouse mammary tumor virus (MMTV)-induced mammary tumors (Robbins et al. 1992). In addition to Notch family genes, other neurogenic genes are also conserved in vertebrates. Several genes related to the groucho transcript of the Drosophila Enhancer of split complex have been isolated (Stifani et al. 1992; Mallo et al. 1993). Genes related to the helix-loop-helix genes of the Enhancer of split complex have also been cloned (Sasai et al. 1992).

In situ hybridization analysis of the RNA expression pattern of the mouse Notch1 gene revealed that expression was first observed in mesoderm and the primitive streak of gastrulating embryos (Franco del Amo et al. 1992; Reaume et al. 1992). However, by mid-gestation Notch1 expression was observed in a number of other sites and was very high in mitotic cells in the central and peripheral nervous systems (Weinmaster et al. 1991; Franco del Amo et al. 1992; Reaume et al. 1992). To begin to examine the role of the Notch1 gene in vivo, we created mice lacking a functional Notch1 gene by targeted disruption in embryonic stem (ES) cells. Mouse embryos homozygous for this mutation die before 11.5 days of gestation, demonstrating that the product of the Notch1 gene plays a vital role during early postimplantation development in mice.

\section{Results}

Targeted disruption of Notchl and germ-line transmission of the mutated allele

We have described previously the isolation of rat and mouse homologs of Notch, and have analyzed the expression pattern of this gene in adults and in early postimplantation embryos (Weinmaster et al. 1991; Franco del Amo et al. 1992, 1993). Initially, we referred to the mouse gene as Motch, following the convention initiated for a Xenopus Notch homolog designated Xotch (Coffman et al. 1990). However, to comply with the Guidelines for Standardized Genetic Nomenclature for Mice (Lyon 1989) and to differentiate this gene from other Notch gene family members (Weinmaster et al. 1992), we have renamed this gene Notch1 (Franco del Amo et al. 1993). To construct a targeting vector for the Notch1 gene, a neo expression cassette was cloned into a unique restriction enzyme site located in an exon encoding EGF repeat 32 (see Materials and methods). This disrupts the reading frame of the Notch1 gene in the extracellular domain of the protein. Because the Notch1 gene was disrupted by cloning the neo expression cassette in an exon encoding EGF repeat 32 (Fig. 1A), we refer to this mutant allele as Notch $1^{\text {in } 32}$.

The linearized targeting vector was electroporated into CJ7 and CJ9 ES cells (Swiatek and Gridley 1993), and the electroporated cells were subjected to positive/negative selection (Mansour et al. 1988) using G418 and FIAU.
Four independently targeted clones of $\mathrm{CJ} 7$ cells and 10 clones of CJ9 cells were identified by polymerase chain reaction (PCR) screening. This represented a targeting frequency of $\sim 1 / 34$ double-selected clones. Mutant clones were expanded and confirmed by Southern analysis with various restriction enzymes (see Fig. 1C). Mutant clones were injected into $\mathrm{C} 57 \mathrm{Bl} / 6$ recipient blastocysts, and male founder animals exhibiting extensive coat-color chimerism were crossed to C57Bl/6 females. Because the ES cells were derived from 129/Sv mice, progeny of the chimeric founders were $F_{1}$ hybrids of the two strains. Germ-line transmission of the Notch1 ${ }^{\text {in32 }}$ allele was obtained for three targeted clones (3-3F, 9-7B, and 5-3B), including at least one clone derived from each parental ES cell line. Notch $1^{\text {in32 }}$ alleles passed through the germ line were analyzed by Southern blotting to confirm that they contained the expected replacement-type homologous recombination event (Fig. 1C). $\mathrm{F}_{1}$ mice heterozygous for the Notch $1^{\text {in } 32}$ mutation appeared phenotypically normal.

\section{Mice homozygous for the Notch $1^{\text {in32 }}$ mutation die before 11.5 days of gestation}

To examine whether animals homozygous for the Notch $1^{\text {in } 32}$ mutation were viable, heterozygous $F_{1}$ animals were intercrossed and genotypes of the $F_{2}$ progeny were determined at 2 or 3 weeks after birth. No mice homozygous for the Notch $1^{\text {in } 32}$ mutation were detected among $104 \mathrm{~F}_{2}$ progeny analyzed (Table 1 ). These data include progeny derived from all three independently targeted ES cell clones. This demonstrated $(P<0.001)$ that the Notch $1^{\text {in32 }}$ allele is a completely penetrant-recessive lethal mutation, even on a segregating genetic background.

To determine when homozygous mutant embryos were dying, embryos were isolated between 8.5 and 11.5 days postcoitum (dpc; morning of detection of the copulation plug is $0.5 \mathrm{dpc}$ ). Embryos (243) obtained from 22 litters were examined (Table 1). All homozygous mutant embryos were already resorbed when isolated at 11.5 $\mathrm{dpc}$. When isolated at $10.5 \mathrm{dpc}$, homozygous mutant embryos were either completely resorbed or were severely retarded, compared with littermate controls (Fig. 2). The homozygous mutant embryos isolated at $10.5 \mathrm{dpc}$ had beating hearts, although the majority had vastly distended pericardial sacs. Histological analysis of these embryos revealed that they were severely necrotic and would certainly be resorbed within the next $24 \mathrm{hr}$ (Fig. 2D,E).

Homozygous mutant embryos isolated at $9.5 \mathrm{dpc}$ were developmentally retarded compared with wild-type and heterozygous littermates. Mutant embryos had generally formed 14-16 somites, compared with 20-25 somites for wild-type and heterozygous littermates. Pattern formation in homozygous mutant embryos, as assessed by morphological and histological analysis, appeared largely normal. Homozygous mutant embryos formed brain vesicles, optic vesicles, branchial arches, otocysts, forelimb buds, a beating heart, and 14-16 somites (Fig. 3A). 


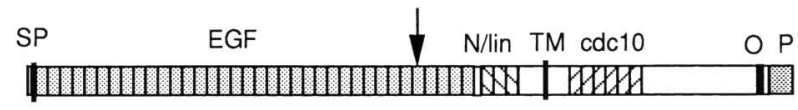

$$
-100 \text { amino acids }
$$

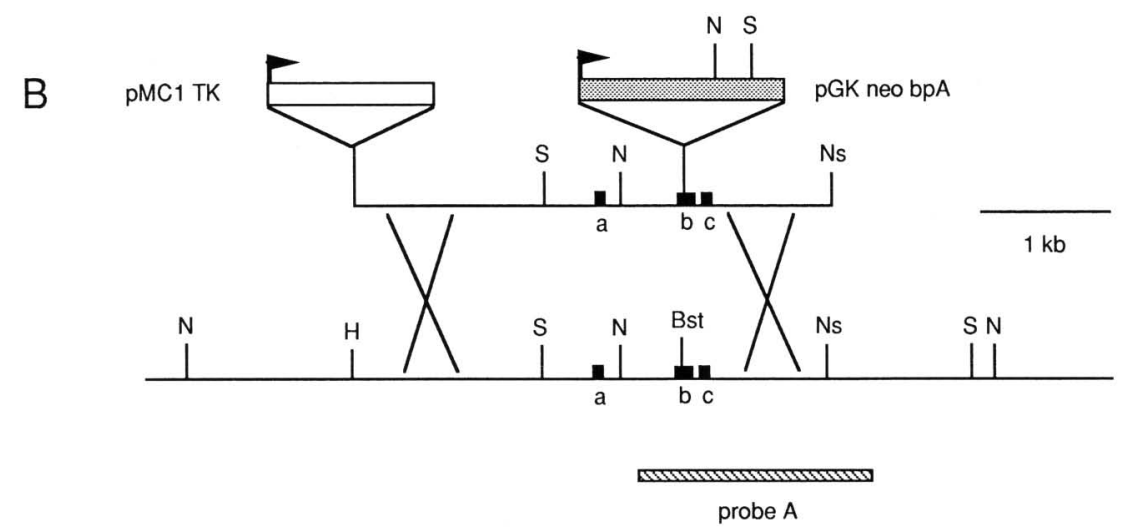

Targeting vector
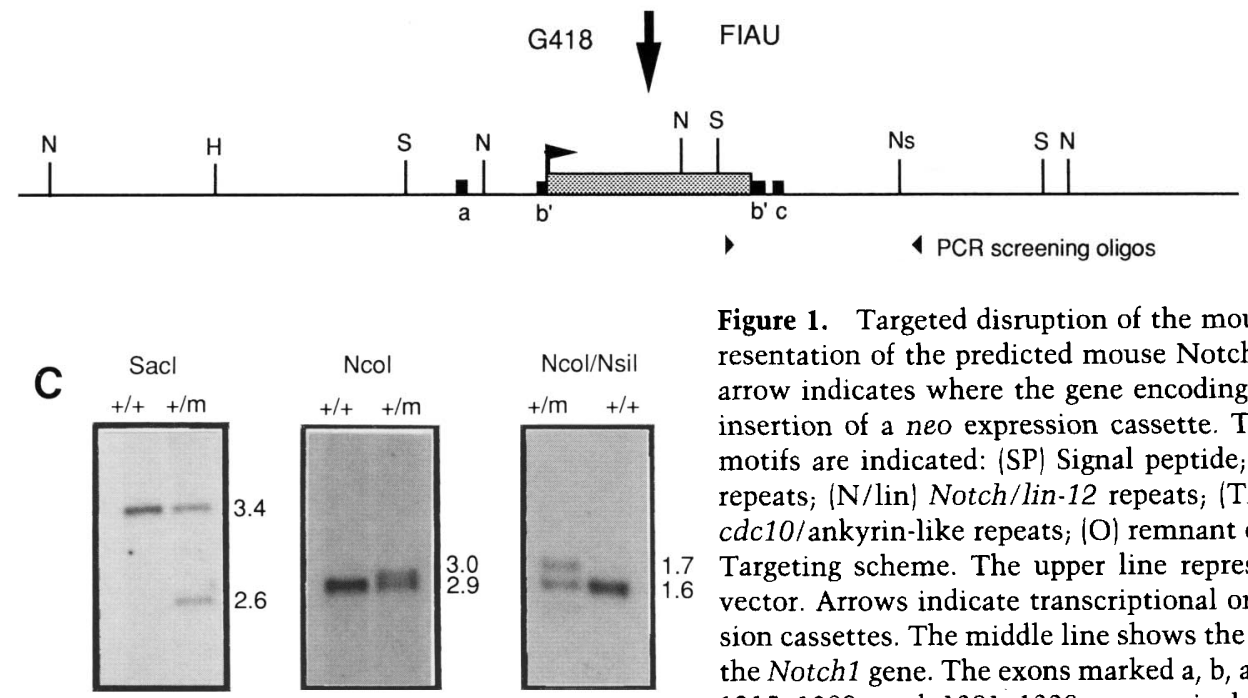

\author{
Expected \\ homologous \\ recombinant
}

Figure 1. Targeted disruption of the mouse Notch1 gene. $(A)$ Schematic representation of the predicted mouse Notch1 protein sequence. The downward arrow indicates where the gene encoding the Notchl protein is disrupted by insertion of a neo expression cassette. The following conserved amino acid motifs are indicated: (SP) Signal peptide; $(\mathrm{EGF})$ epidermal growth factor-like repeats; (N/lin) Notch/lin-12 repeats; (TM) transmembrane domain; (cdc10) cdc10/ankyrin-like repeats; $(\mathrm{O})$ remnant of opa repeat; (P) PEST sequence. $(B)$

1.7 Targeting scheme. The upper line represents the structure of the targeting vector. Arrows indicate transcriptional orientation of the $T K$ and neo expression cassettes. The middle line shows the genomic organization of a portion of the Notch1 gene. The exons marked $a, b$, and c encode amino acids 1171-1214, 1215-1300, and 1301-1338, respectively, of the predicted Notchl protein (Franco del Amo et al. 1993). The neo expression cassette was cloned into a unique BstXI site in exon b. Additional uncharacterized exons are present both $5^{\prime}$ and $3^{\prime}$ to the exons shown. Shown at the bottom is the predicted structure of the Notch1 locus following homologous recombination of the targeting vector. The PCR primers used for screening are indicated by arrowheads. The hybridization probe used for Southern blot analysis is indicated. Restriction enzymes: (Bst) BstXI; (H) HindIII; (N) NcoI; (Ns) NsiI; (S) SacI. (C) Southern blot analysis of DNA from Notch1 $1^{\text {in } 32} /+$ and $+/+$ mice. DNA isolated from tail biopsies of 2-week-old progeny of the intercross of $\operatorname{Notch}^{i n 32} /$ + heterozygous mice was digested with the indicated restriction enzymes, Southern blotted, and hybridized with probe A. Sizes of hybridizing restriction fragments are indicated. Note the reduction in hybridization intensity of the wild-type fragment in the heterozygous $(+/ \mathrm{m})$ animals. Because probe A spans the unique BstXI site used for introduction of the neo expression cassette, digestion of DNA from heterozygous animals also yields additional faintly hybridizing restriction fragments from the Notch $1^{\text {in32 }}$ mutant allele. In the SacI digest, the $2.6-\mathrm{kb}$ band in the heterozygote is actually a doublet, and in the Ncol digest a faintly-hybridizing $1.5-\mathrm{kb}$ band is also present in the heterozygotes. The animals shown were derived from ES cell clone 9-7B. Analysis of progeny of the other two ES cell clones (3-3F and 5-3B) gave identical results.

Somite condensation in the homozygous mutant embryos appeared to cease after formation of the first 14-16 somites-no homozygotes with larger numbers of somites were observed.

Histological analysis of embryos isolated at $9.5 \mathrm{dpc}$ revealed localized areas of cell death. Cell death did not appear random but appeared preferentially in portions of the central and peripheral nervous systems. Pycnotic cells were found in neuroepithelium of the central nervous system, particularly in the optic lobe and the hind- 
Swiatek et al.

Table 1. Genotypes of progeny of $F_{1}$ intercrosses of $\operatorname{Notch}^{\mathrm{in} 32} /+$ heterozygous mice

\begin{tabular}{|c|c|c|c|c|c|c|c|c|}
\hline \multirow[b]{2}{*}{ Stage } & \multirow{2}{*}{$\begin{array}{l}\text { Number } \\
\text { of litters }\end{array}$} & \multirow{2}{*}{$\begin{array}{l}\text { Total mice } \\
\text { or embryos }\end{array}$} & \multirow[b]{2}{*}{ Resorbed } & \multicolumn{3}{|c|}{ Genotypes } & \multirow[b]{2}{*}{$x^{2}$} & \multirow[b]{2}{*}{$P$} \\
\hline & & & & $+1+$ & $+1-$ & $-1-$ & & \\
\hline Adult & 13 & 104 & N.A. & 45 & 59 & 0 & 40.82 & $<0.001$ \\
\hline $8.5 \mathrm{dpc}$ & 8 & 87 & 1 & 28 & 38 & 19 & 2.86 & $>0.05$ \\
\hline $9.5 \mathrm{dpc}$ & 5 & 59 & 1 & 22 & 24 & 12 & 5.17 & $>0.05$ \\
\hline $10.5 \mathrm{dpc}$ & 4 & 43 & 3 & 20 & 13 & 7 & 13.35 & $<0.01$ \\
\hline $11.5 \mathrm{dpc}$ & 5 & 44 & 14 & 10 & 20 & 0 & 10.00 & $<0.01$ \\
\hline
\end{tabular}

The adult genotype analysis combines data from mice derived from clones 9-7B, 3-3F, and 5-3B. The embryonic genotype analysis combines data from mice derived from clones 9-7B and 3-3F. Genotypes of adult mice were determined by PCR analysis or Southern analysis of tail DNA. Mice grouped in the adult category were 10 days old or older at the time of tail biopsy. Genotypes of embryos were determined either by PCR analysis or Southern analysis of yolk sac DNA. Resorptions were not genotyped. Ratios of genotypes were tested for goodness of fit to expected Mendelian segregation $(1: 2: 1)$ by $\chi^{2}$ analysis, calculated for two degrees of freedom. (N.A.) Not applicable.

brain, and in neural crest-derived cells that were condensing to form cranial sensory ganglia, such as the trigeminal (V) and the facial/acoustic (VII/VIII) ganglia (Fig. 3). Histological analysis did not reveal hypertrophy of neural or other tissues in homozygous mutant embryos (Fig. 3; data not shown). Mutant phenotypes were identical for embryos derived from either of the ES cell clones 9-7B or 3-3F. When isolated at $8.5 \mathrm{dpc}$, homozygous mutant embryos were morphologically indistinguishable from wild-type or heterozygous littermates (data not shown).
We were interested in seeing whether the Notch1 $1^{\text {in } 32}$ mutation affected neuronal differentiation in the homozygous mutant embryos. To test this, we assayed Notch $1^{\text {in32 }}$ homozygous mutant embryos and littermate controls by whole-mount immunohistochemistry with a monoclonal antibody to the $155-\mathrm{kD}$ neurofilament protein (Dodd et al. 1988). This analysis showed that neurofilament-positive cells did form in the homozygous mutant embryos (Fig. 4). Furthermore, cranial neural crest migrating from the midbrain and hindbrain to form the cranial sensory ganglia appeared to be correctly pat-
Figure 2. Morphological and histological analysis of embryos from the intercross of Notch $1^{\text {in } 32} /$ + heterozygous mice, isolated at 10.5 days of gestation. (A) Morphology of a wild-type embryo (left) and three homozygous mutant littermates isolated at $10.5 \mathrm{dpc}$. $(B, C)$ Higher magnification views of homozygous mutant embryos shown in A (first and third from right, respectively). Note the vastly distended pericardium, which is frequently observed in homozygous mutants isolated at this stage. $(D)$ Transverse section of embryo shown in $C$. This embryo is severely necrotic, with extensive degeneration in the neuroepithelium of the hindbrain(ne), in the epithelium of the otic vesicle (ot), and in cephalic mesenchyme. $(E)$ Parasagittal section of embryo shown in $B$. Densely staining pycnotic cells are again seen in both neuropeithelium and mesenchyme, although this embryo is not as necrotic as its littermate shown in $C$ and $D .(D, E)$ Magnification, $400 \times$. (ne) Neuroepithelium; (ot) otic vesicle.

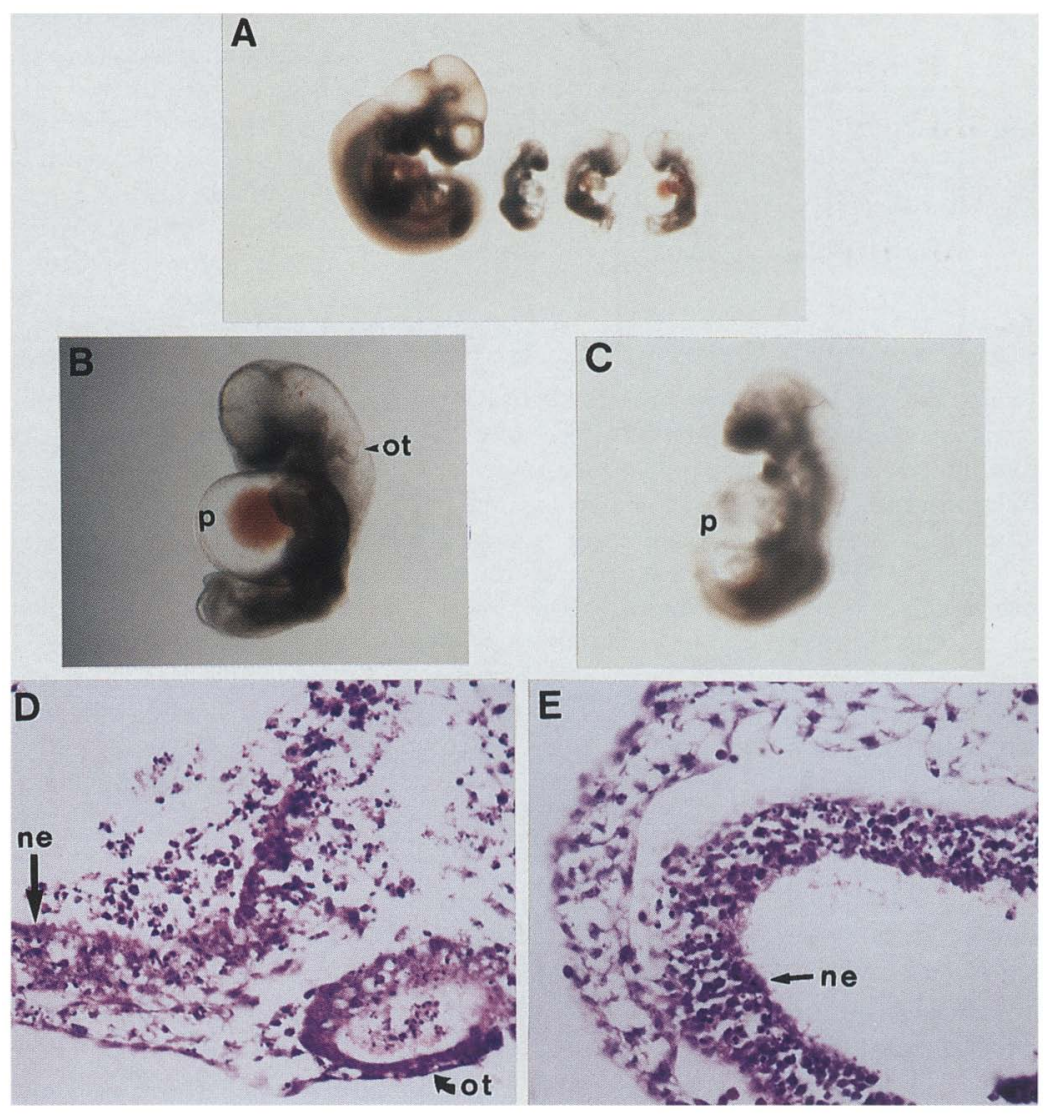




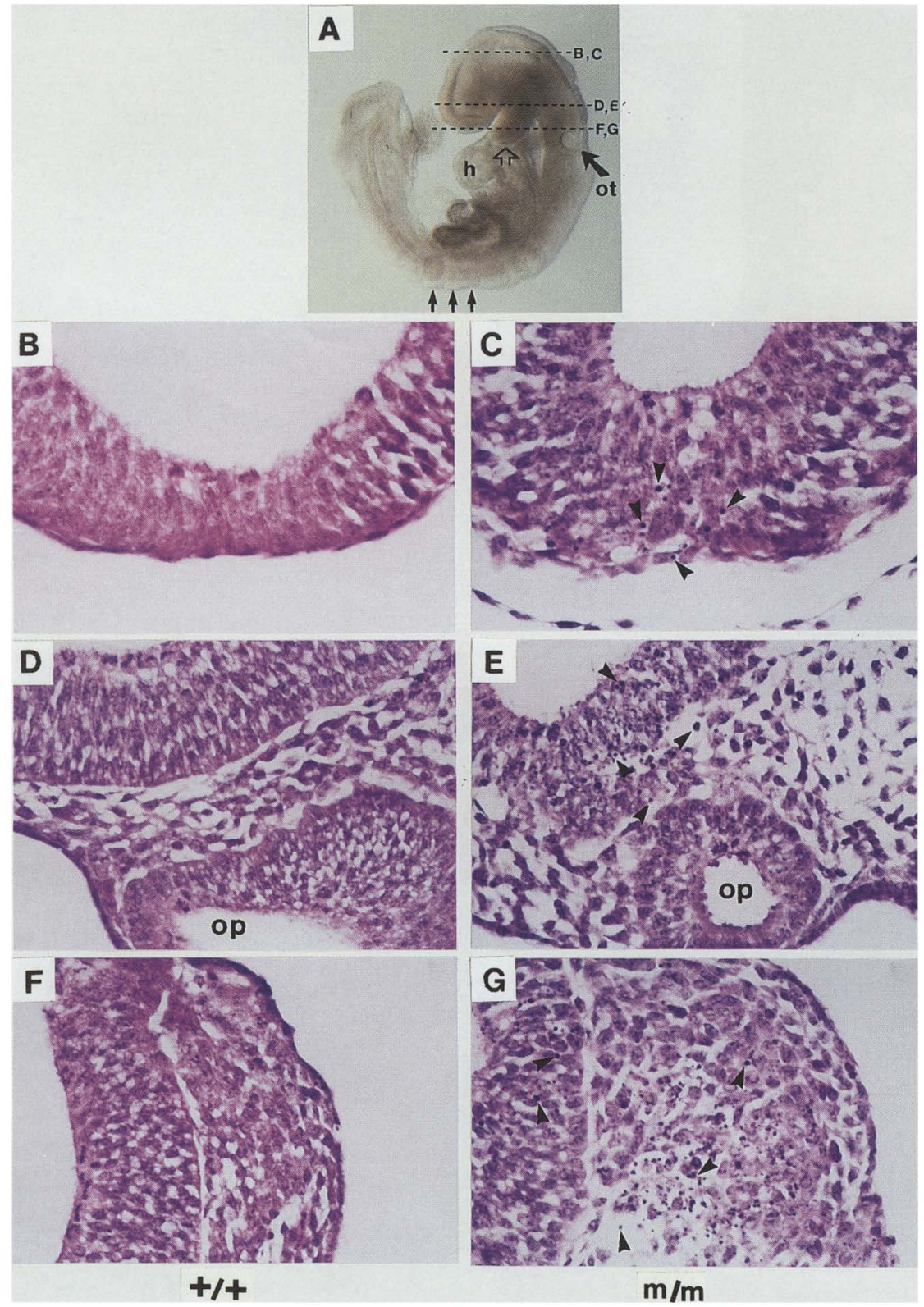

Figure 3. Morphological and histological analysis of embryos from intercrosses of Notch $^{1 \text { in } 32 /+~ h e t e r o z y g o u s ~ m i c e, ~ i s o l a t e d ~}$ at 9.5 days of gestation. (A) Whole-mount morphology of homozygous mutant embryo isolated at $9.5 \mathrm{dpc}$. The broken lines indicate the approximate planes of section of the indicated panels. Note the presence in this mutant embryo of the otic vesicle, heart, branchial arch (open arrow), and somites (solid arrows). (B-G) Serial transverse sections of a Notch $1^{\text {in } 32}$ homozygous mutant embryo $(C, E, G)$ and a wild-type littermate $(B, D, F)$ isolated at $9.5 \mathrm{dpc} .(B, C)$ Transverse sections through neuroepithelium near the top of the head. Pycnotic cells (densely stained with hematoxylinsome are indicated by arrows) are observed in the neuroepithelium of the mutant embryo. $(D, E)$ Transverse sections at the level of the optic vesicle. Pycnotic cells (some of which are indicated by arrows) are observed in the mutant embryo in neuroepithelium adjacent to the optic vesicle. $\{F, G\}$ Transverse sections at a level just rostral to the otic vesicle. Pycnotic cells are observed in the mutant embryo in the neuroepithelium of the hindbrain and in neural crest that is condensing to form the facial/ acoustic (VII/VIII) ganglion. Magnifications $640 \times(B, C) ; 500 \times(D-G)$. (h) Heart; (op) optic vesicle; (ov) otic vesicle. terned, as the primordia for cranial ganglia V, VII/VIII, IX, and X were clearly visible in their proper locations (Fig. 4B). The primordia for these ganglia were also apparent upon histological analysis (Fig. 3).

We also wanted to determine whether the Notch $1^{\text {in } 32}$ mutation affected the accumulation of stable Notch1 transcripts. Therefore, we analyzed wild-type and homozygous mutant embryos by whole-mount in situ hybridization. The probe, which we had used previously to examine Notch1 RNA expression by in situ hybridization of sectioned embryos (Franco del Amo et al. 1992), was located 3' of the insertion site of the neo expression cassette used to disrupt the Notch1 gene. Embryos were analyzed at $8.5 \mathrm{dpc}$, before there were any obviously detectable morphological differences between wild-type and homozygous mutant embryos. Wild-type embryos exhibited a strong band of Notch1 expression in presomitic mesoderm (Fig. 5A). Expression was highest just posterior to the last condensed somite. Lower levels of expression were observed in the remainder of the presomitic mesoderm. This band of Notch1 expression marking the nascent somite had been observed previously by Reaume et al. (1992). We could not detect Notch1 expression in Notch $1^{\text {in32 }}$ homozygous mutant embryos (Fig. 5B) and conclude that the Notch $1^{\text {in } 32}$ mutation does interfere with accumulation of stable Notch1 transcripts.

Mice homozygous for the Notch $1^{\text {in } 32}$ mutation
do not appear to die because of defects
in placentation or vascularization

The time of death of Notch1 $1^{\text {in32 }}$ homozygous mutant 


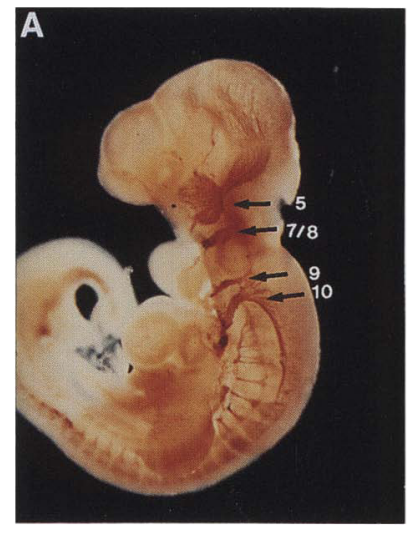

$+1+$

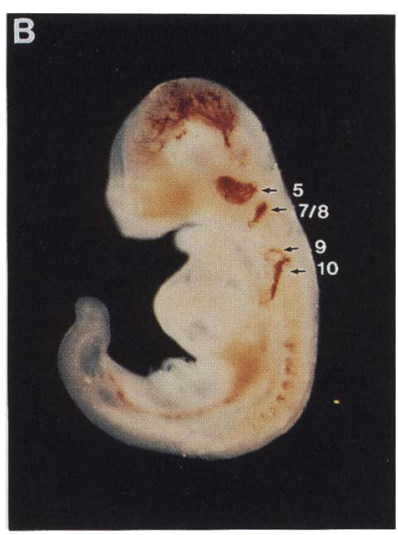

$\mathrm{m} / \mathrm{m}$

Figure 4. The Notch $1^{\text {in32 }}$ mutation does not inhibit neuronal differentiation or affect patterning of cranial neural crest. Whole-mount immunohistochemistry with an anti-neurofilament monoclonal antibody of a Notch $1^{\text {in } 32}$ homozygous mutant embryo $(B)$ and a wild-type littermate $(A)$ isolated at $9.5 \mathrm{dpc}$. Although the homozygous mutant embryo is clearly developmentally retarded compared with its wild-type littermate, neurofilament positive cells differentiate and the cranial sensory ganglia develop in their normal location in the mutant embryo. Cranial ganglia are numbered as follows: $(5)$ trigeminal; $(7 / 8)$ facial/acoustic; (9) glossopharyngeal; (10) vagus.

embryos coincides approximately with the time during mouse embryogenesis when the placenta begins to form and function. For example, mice that are homozygous for the Brachyury $(T)$ mutation die at a similar time as the homozygous Notch $1^{\text {in32 }}$ mutant embryos, because of failure of the allantois to fuse with the chorion (Gluecksohn-Schoenheimer 1944). Cells of the allantois contribute to the formation of the endothelial cells lining the blood vessels in the umbilical cord (Snell and Stevens 1966; Theiler 1989; Rugh 1990; Kaufman 1992). To exclude defects in placentation as the cause of death of the mutant embryos, we examined carefully whether early steps in formation of the placenta were occurring in Notch $1^{\text {in } 32}$ homozygous mutant embryos. The allantois of homozygous mutant embryos appeared normal and fused with the chorion at the normal time, by about the 6-somite stage (data not shown).

Because the Notch1 gene is expressed in endothelial cells (Franco del Amo et al. 1992), we also were concerned that vascularization might be affected in homozygous mutant embryos. However, red blood cells, which arise in the yolk sac blood islands and migrate into the embryo through the vitelline vessels of the umbilical cord, were present in blood vessels and the heart in the homozygous mutant embryos (Fig. 2A,B; data not shown). We also examined vascularization and endothelial cell development using whole-mount in situ hybridization with a probe for the receptor tyrosine kinase flk-1 (Matthews et al. 1991), which has been shown to be an early marker for endothelial cells and their precursors (Yamaguchi et al. 1993). As described previously (Yamaguchi et al. 1993), whole-mount in situ hybridization

of wild-type embryos at $9.5 \mathrm{dpc}$ with an antisense flk-1 probe revealed endothelial cells forming an extensive network of anastomosing blood vessels (Fig. 6A). Hybridization of Notch $1^{\text {in } 32}$ homozygous mutant embryos showed a similar pattern of flk-1-expressing endothelial cells as the wild-type littermates (Fig. 6B). Thus, death of

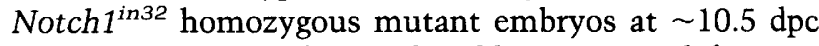
does not appear to be attributable to major defects in either placentation or vascularization.

\section{The RNA expression pattern of the Notch2 gene} partially overlaps the Notchl expression pattern and is not detectably altered in Notch $1^{\text {in } 32}$ homozygous mutants

Recently, we described the cloning of a second vertebrate Notch gene family member, Notch2, and analyzed its RNA expression pattern during late embryogenesis and in adults (Weinmaster et al. 1992). This analysis indicated that in rat embryos at $16.5 \mathrm{dpc}$, expression of the Notch1 and Notch2 genes was distinct and included both overlapping and nonoverlapping sites of expression. We were interested, however, in examining the Notch2 RNA expression pattern in early postimplantation embryos and in determining whether this expression pat-

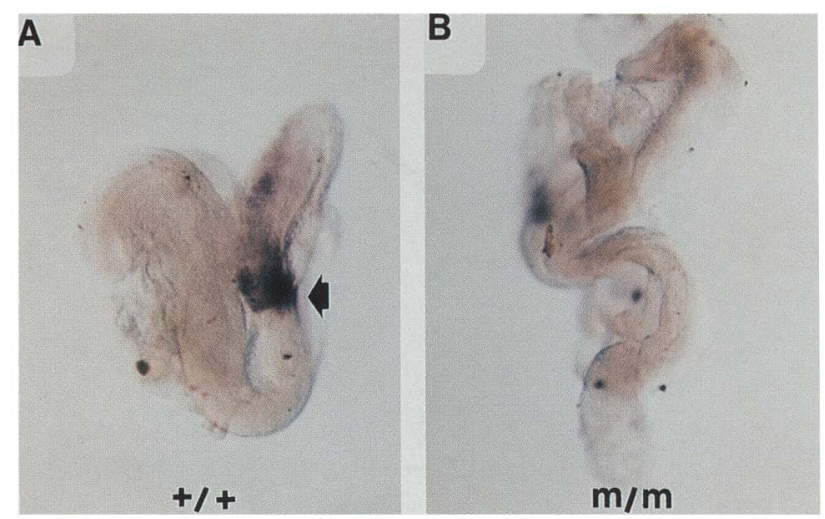

Figure 5. Whole-mount in situ hybridization analysis of

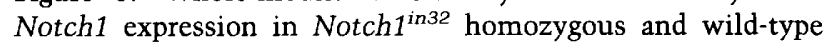
embryos. Embryos from the intercross of Notch1 $1^{\text {in } 32} /+$ heterozygous mice were isolated at $8.5 \mathrm{dpc}$ and processed for wholemount in situ hybridization with a Notch1 antisense RNA probe. $(A)$ Wild-type littermate and $(B)$ Notch $1^{\text {in } 32}$ homozygous mutant embryo. Hybridization signal was observed only in the wild-type embryo. Wild-type embryos exhibited a strong band of Notch1 expression in presomitic mesoderm (arrow). Expression was highest just posterior to the last condensed somite. Lower levels of expression were observed in the remainder of the presomitic mesoderm. No signal was detected in the homozygous mutant embryos. The more extended shape of the homozygous mutant embryo was a result of the dissection and does not reflect a general morphological difference between homozygous mutant and wild-type littermates at this stage of gestation. The small dots present on both embryos represent particulates that adhered to the embryos after proteinase $\mathrm{K}$ treatment [orientation of embryos: (A) anterior of embryo, left; (B) anterior, top]. 


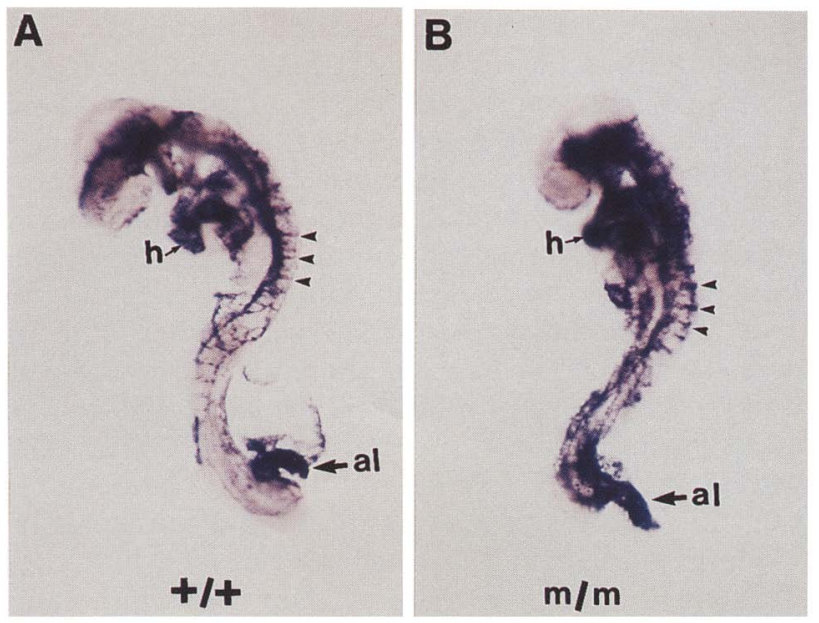

Figure 6. Vascularization, as assessed by in situ hybridization with a probe for the receptor tyrosine kinase $f 1 k-1$, appears normal in Notch $1^{\text {in } 32}$ homozygous mutant embryos. Embryos from the intercross of Notch $1^{\text {in } 32} /+$ heterozygous mice were isolated at $9.5 \mathrm{dpc}$ and were processed for whole-mount in situ hybridization with a mouse $f l k-1$ antisense RNA probe. $(A)$ Wild-type littermate; $(B)$ Notch $1^{\text {in32 }}$ homozygous mutant embryo. In both embryos, flk-1-expressing endothelial cells form an extensive network of anastomosing blood vessels.

tern was altered in Notch $1^{\text {in } 32}$ homozygous mutant embryos. Early headfold-stage and 15-somite-stage rat embryos were analyzed for expression of Notch 2 transcripts by whole-mount in situ hybridization. Notch2 expression was high in the intraembryonic paraxial mesoderm of head-fold stage embryos (Fig. 7A). A strong band of Notch2 expression was also detected in the most recently formed somites of the 15-somite-stage embryos (Fig. 7B). Lower levels of Notch2 expression were observed in the remaining somites, decreasing in intensity
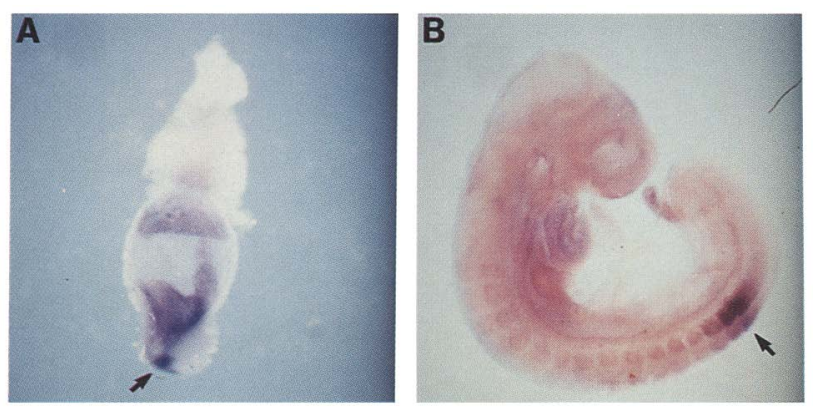

Figure 7. Whole-mount in situ hybridization analysis of Notch2 expression in wild-type rat embryos. Embryos were processed for whole-mount in situ hybridization with a rat Notch2 antisense RNA probe. The rostral ends of embryos are to the left of each panel. $(A)$ Headfold-stage embryo $(9.5 \mathrm{dpc})$. Notch2 expression was observed in the intraembryonic paraxial mesoderm (arrow). $(B)$ 15-Somite stage embryo (10.5 dpc). Notch2 expression was highest in the two most caudal pairs of somites (arrow). Lower levels of Notch2 expression were observed in the remaining somites, decreasing in intensity towards the rostral somites.

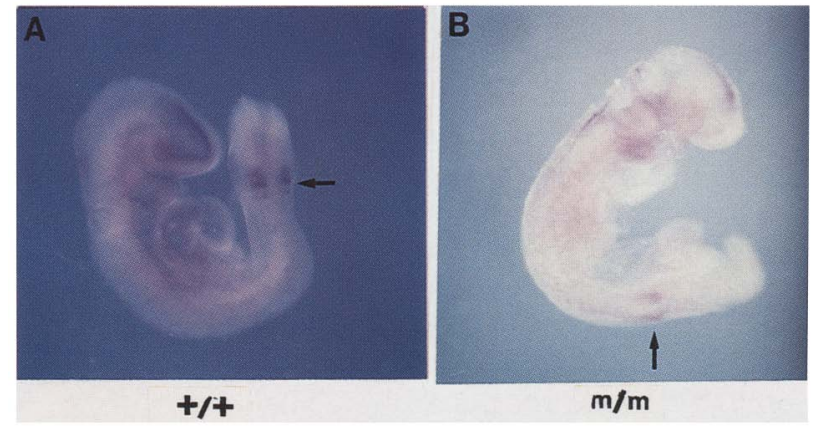

Figure 8. Whole-mount in situ hybridization analysis of Notch2 expression in wild type and Notch $1^{\text {in32 homozygous }}$ mouse embryos. Embryos from the intercross of $N o t c h 1^{i n 32} /+$ heterozygous mice were isolated at $9.5 \mathrm{dpc}$ and processed for whole-mount in situ hybridization with a rat Notch2 antisense RNA probe. $(A)$ Notch2 expression in a wild-type embryo. Although use of the rat probe on mouse embryos gave slightly higher background staining, particularly in the telencephalon, Notch2 expression was observed in the caudal pairs of somites (arrow). (B) Notch2 expression in a Notch $1^{\text {in } 32}$ homozygous mutant mouse embryo. Notch2 expression was observed in the most caudal pair of somites (arrow) and to a lesser extent in the more rostral somites.

toward the rostral somites (Fig. 7B). Thus, expression of the Notch2 and Notch1 genes partially overlap at these stages of development. However, Notch 2 expression persists in formed somites (Fig. 7B), whereas Notch1 expression is substantially down-regulated upon somite condensation (Franco del Amo et al. 1992; Reaume et al. 1992).

We also examined expression of the Notch 2 gene in wild-type, Notch $1^{\text {in32 }}$ heterozygous, and Notch $1^{\text {in32 }}$ homozygous mouse embryos isolated at $9.5 \mathrm{dpc}$ (Fig. 8; data not shown). Again, Notch2 expression was observed in the most recently formed pair of somites. Thus, using whole-mount in situ hybridization, no distinct differences in the Notch2 RNA expression pattern were detected among wild-type, Notch $1^{\text {in } 32}$ heterozygous, and

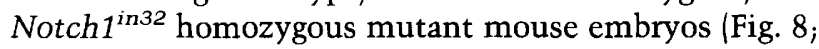
data not shown).

\section{Notchl is not allelic to Danforth's short tail}

We and others have shown previously that the Notch1 gene maps to the proximal region of mouse chromosome 2 (Reaume et al. 1992; Franco del Amo et al. 1993; Kopan and Weintraub 1993). This region of mouse chromosome 2 contains an area of homology to the long arm of human chromosome 9 where the human Notch1 homolog, the TAN-1 gene, has been localized (9q34.3) (Ellisen et al. 1991). Examining this region of the mouse chromosome for mutations described previously which might be located in the Notch1 gene revealed a single candidate locus, Danforth's short tail $(S d)$. $S d$ is a spontaneous mutant identified by Danforth (1930). Heterozygous $S d$ mice have a short tail with a reduced number of caudal vertebrae and some kinking (Dunn et al. 1940; Grüneberg 1953). Homozygotes lack a recognizable notochord, particularly toward the caudal end /Grüneberg 1958; 
Theiler 1959; Bovolenta and Dodd 1991), and die shortly after birth. The Notch1 gene is not expressed in the notochord, and in Notch $1^{\text {in32 }}$ homozygous mutant embryos the notochord is present. However, certain features of the $S d$ mutation (e.g., existence of a single, spontaneously isolated mutant allele and presence of a heterozygous phenotype) suggest that $S d$ may be a gainof-function mutation. Because the phenotypic effects of such a mutation may be more difficult to predict than that of a null mutation, we examined whether the Notch $1^{\text {in } 32}$ mutation and $S d$ were allelic.

Analysis of the progeny of the mating of $N o t c h 1^{i n 32 /+}$ heterozygous mice with $S d /+$ heterozygous mice indicated that the two mutations complemented each other fully, as 12 of 27 progeny containing the $S d$ chromosome also contained the Notch $1^{\text {in } 32}$ chromosome. However, genetic analysis in Drosophila has shown that different Notch alleles can participate in extremely complex complementation patterns (Welshons 1971; Foster 1975; Portin 1975; for review, see Artavanis-Tsakonas et al. 1991). Therefore, to confirm that Notch1 and $S d$ are not allelic and to determine the genetic distance separating them, we performed a backcross analysis to detect recombination between these two loci. This analysis indicated that $S d$ and Notch1 are $\sim 10$ centiMorgans distant from each other $(11 / 107$ recombinant progeny $=10.2 \pm 2.9 \mathrm{cM}$; Table 2). Because only these two markers were segregating in the cross, we have not established in this experiment on which side of $S d$ the Notch1 gene is located. However, because the homology region to human chromosome 9q (where the human Notch1 gene maps; Ellisen et al. 1991) lies distal to $S d$ on mouse chromosome 2 (Lyon and Kirby 1993), it is probable that Notch1 lies distal to $S d$ as well.

\section{Discussion}

The Notch $1^{\text {in } 32}$ phenotype

The work presented here demonstrates that a functional
Notch1 gene is essential for postimplantation development in mice. Embryos homozygous for the Notch $1^{\text {in } 32}$ allele died and were resorbed by 11.5 days of gestation. Considerable postimplantation development takes place in homozygous mutant embryos. As assessed by morphological and histological criteria, the Notch1 product is not required for largely normal pattern formation through $\sim 9$ days of gestation. Although we cannot exclude the possibility that small populations of cells might be missing or have an altered fate, homozygous mutant embryos form brain vesicles, branchial arches, otocysts, a beating heart and the first 14-16 somites. The main phenotype that we have observed in the homozygous mutant embryos is widespread cell death. Initially, cell death does not appear at random but seems to occur preferentially (but not exclusively) in neuroepithelium and in neurogenic neural crest. We have also ruled out obvious defects in placentation or vascularization as the cause of death of homozygous mutant embryos.

It does not appear, then, that Notch1 function is obligately required for the formation of the first tissues to express the gene. Notch1 RNA expression is first detected in mesoderm and the primitive streak of gastrulating embryos (Franco del Amo et al. 1992; Reaume et al. 1992). Notch1 is expressed at very high levels in presomitic mesoderm of $8.5 \mathrm{dpc}$ embryos but is down-regulated upon formation of somites. When analyzed by whole-mount in situ hybridization, an intense band of Notch1 expression appears to mark the nascent somite (Fig. 5; Reaume et al. 1992). This observation prompted the suggestion that Notch1 might be involved in promoting the cell-cell interactions leading to somite formation (Reaume et al. 1992). However, our results indicate that Notch1 function is not obligately required either for formation of mesoderm or its condensation to form somites.

Two possibilities could explain the lack of an obvious phenotype affecting mesoderm formation or somite condensation in Notch $1^{\text {in32 }}$ homozygous mutant embryos. The first possibility is that Notch1 is not involved in

Table 2. Recombination between Sd and the Notchl locus

\begin{tabular}{|c|c|c|c|}
\hline Cross $^{a}$ & Progeny genotypes & Number observed & Class $^{b}$ \\
\hline$\underset{\times}{\left(S d N 1^{+R S V} / S d^{+} N 1^{i n 32}\right)}$ & $S d N 1^{+R S V} / S d^{+} N 1^{+C 57}$ & 14 & $P$ \\
\hline$\left(S d^{+} N 1^{+C 57} / S d^{+} N 1^{+C 57}\right)$ & $\begin{array}{l}S d^{+} N 1^{i n 32} / S d^{+} N 1^{+C 57} \\
S d N 1^{i n 32} / S d^{+} N 1^{+C 57} \\
S d^{+} N 1^{+R S V} / S d^{+} N 1^{+C 57}\end{array}$ & $\begin{array}{r}16 \\
0 \\
2\end{array}$ & $\begin{array}{l}\mathrm{P} \\
\mathrm{R} \\
\mathrm{R}\end{array}$ \\
\hline$\left(S d N 1_{\times}^{+R S V} / S d^{+} N 1^{+C 57}\right)$ & $S d N 1^{+R S V} / S d^{+} N 1^{+C 57}$ & 31 & $P$ \\
\hline$\left(S d^{+} N 1^{+C 57} / S d^{+} N 1^{+C 57}\right)$ & $\begin{array}{l}S d^{+} N 1^{+C 57} / S d^{+} N 1^{+C 57} \\
S d N 1^{+C 57} / S d^{+} N 1^{+C 57} \\
S d^{+} N 1^{+R S V} / S d^{+} N 1^{+C 57}\end{array}$ & $\begin{array}{r}35 \\
6 \\
3\end{array}$ & $\begin{array}{l}\mathrm{P} \\
\mathrm{R} \\
\mathrm{R}\end{array}$ \\
\hline
\end{tabular}

Totals: Recombinant/recombinant \pm parental $11 / 107=10.2 \pm 2.9 \mathrm{cM}$.

${ }^{2}$ Allele designations: $(S d)$ Mutant allele at Danforth's short tail $(S d)$ locus; $\left(S d^{+}\right)$wild-type allele at the $S d$ locus; $\left(N 1^{\text {in32) }}\right.$ mutant allele at Notch1 locus; $\left(N 1^{+R S V}\right)$ wild-type allele at Notch1 locus in the RSV/Le mouse $\operatorname{strain}_{;}\left(N 1^{+C 57}\right)$ wild-type allele at Notch1 locus in the $\mathrm{C} 57 \mathrm{Bl} / 6$ and $129 / \mathrm{Sv}$ mouse strains.

b(P) Parental; (R) recombinant. 
these processes. However, work in Drosophila has established that Notch mutants have effects in all three germ layers (Corbin et al. 1991; Hartenstein et al. 1992). An alternative possibility is that Notch1 is involved in these processes but that its loss in Notch $1^{\text {in } 32}$ mutants is functionally compensated by the expression of another Notch gene. Functional compensation (or redundancy) has been demonstrated recently in the formation of skeletal muscle in mice (Rudnicki et al. 1993), has been invoked to explain the lack of a phenotype in the caudal hindbrain and spinal cord of Wnt-1 mutant mice (McMahon et al. 1992), and also has been implicated in the interpretation of mutant phenotypes of several other targeted or insertional mutations in mice (for review, see Gridley 1991). Functional redundancy of genes and genetic pathways has been described previously in a number of other organisms (see, e.g., Kataoka et al. 1984; Ferguson and Horvitz 1989; for review, see Thomas 1993|. We find that expression of the Notch2 gene overlaps expression of the Notch1 gene in presomitic mesoderm. Furthermore, recent work in C. elegans indicates that different Notch gene family members may be, to a large degree, functionally interchangeable. While studying the Notch-related genes Iin-12 and glp-1, Fitzgerald et al. (1993) expressed glp-1 protein under the control of lin-12 regulatory sequences in lin-12 null mutant animals. They found that glp-1 could substitute for lin- 12 in mediating several cell fate decisions, suggesting that the two proteins were functionally interchangeable even though they shared only $50 \%$ sequence identity. Partial genetic redundancy of $I i n-12$ and $g l p-1$ was also indicated by the novel phenotype displayed by lin-12/glp-1 double mutants (Lambie and Kimble 1991) and by the ability of a particular neomorphic $g l p$-1 allele to mimic dominant gain-of-function lin-12 mutations (Mango et al. 1991). To answer the question of possible functional redundancy between Notch1 and Notch2 gene products in mice will require the examination of the phenotypes of Notch2 mutant animals and Notch1/Notch2 double mutants.

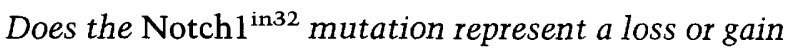 of function?}

Several reports have appeared recently that describe the phenotypes attributable to expression of truncated constructs of Notch family genes in Drosophila or C. elegans (Fortini et al. 1993; Lieber et al. 1993; Rebay et al. 1993; Roehl and Kimble 1993; Struhl et al. 1993; for review, see Fortini and Artavanis-Tsakonas 1993; Sternberg 1993). These truncated constructs express the cytoplasmic domains of the Notch, glp-1, or lin-12 proteins in the absence of all or of the majority of the extracellular domains of these proteins. The common finding of these studies is that expression of the cytoplasmic domains of these proteins causes a dominant gain-of-function phenotype.

Several examples of the expression of truncated Notch family genes have also been examined in vertebrates. Two mammalian Notch gene family members, the human Notch1 gene (TAN-1; Ellisen et al. 1991) and the mouse int-3 gene (Robbins et al. 1992), were cloned as oncogenes. In both of these cases, it appears that deregulated expression of a truncated RNA encoding the cytoplasmic domain of the protein contributes to the tumorigenic phenotype (Ellisen et al. 1991; Jhappan et al. 1992). Coffman et al. (1993) described the phenotype resulting from the injection into Xenopus embryos of RNA encoding an extracellular deletion of the Xenopus Notch1 gene (which they term Xotch-the truncated form is termed Xotch $\Delta \mathrm{E}$ ). Xotch $\Delta \mathrm{E}$ embryos exhibit a complete absence of anterior structures such as the cement gland and the eyes. There was also an enlargement and disorganization of other dorsoanterior structures such as the forebrain, spinal cord, and otic vesicle (Coffman et al. 1993). Mosaic expression of the Xotch $\Delta \mathrm{E}$ construct revealed a hypertrophy of the neural tube and of muscle tissue. This hypertrophy of neural and muscle tissue was readily apparent in histological sections of Xotch $\Delta \mathrm{E}$-injected embryos. Coffman et al. propose that Xotch $\Delta \mathrm{E}$ represents a dominantly activated (i.e., gain-offunction) form of Xotch.

The phenotype observed in Xotch $\Delta \mathrm{E}$-injected embryos is in marked contrast to the phenotype that we observe in Notch $1^{\text {in } 32}$ homozygous mutant embryos. The Notch $1^{\text {in32 }}$ homozygotes exhibit no loss or disorganization of dorsoanterior structures nor do they exhibit a hypertrophy of neural or muscle tissue apparent in histological sections. We suggest that the Notch $1^{\text {in } 32}$ allele represents a loss-of-function mutation. The neo expression cassette used for construction of the targeting vector, PGKneobpa (Soriano et al. 1991), contains a strong polyadenylation site and termination codons in all three reading frames. In addition, we have shown that the Notch $1^{\text {in } 32}$ mutation interferes with stable Notch1 RNA accumulation and that $N o t c h 1^{\text {in } 32} /+$ heterozygous animals exhibit no obvious phenotype. Also, numerous chromosomal rearrangements or insertions with breakpoints in the region of the Drosophila Notch gene encoding the extracellular domain of the protein exhibit loss-of-function phenotypes (Kidd et al. 1983; Grimwade et al. 1985). Thus, the differences in phenotype observed between Xotch $\Delta \mathrm{E}$-injected frog embryos and Notch $1^{\text {in } 32}$ homozygous mouse embryos likely represent the differences between gain-of-function and loss-of-function alleles of the same gene. To test this hypothesis, experiments are in progress to express truncated Notch1 constructs in transgenic mice.

The work described here demonstrates that a functional Notch1 gene is required for normal postimplantation development in mice. However, it will be important to construct and analyze additional mutations in the Notch1 gene. In a number of instances of targeted gene disruption in mice, different mutant alleles have exhibited quite different phenotypes [see, e.g., Hoxa-1 (Hox1.6; Lufkin et al. 1991; Chisaka et al. 1992); N-myc (Charron et al. 1992; Moens et al. 1992, 1993; Stanton et al. 1992); cystic fibrosis transmembrane conductance regulator (Clarke et al. 1992; Dorin et al. 1992; Snouwaert et al. 1992/]. In addition, work in Drosophila has shown that different Notch alleles can exhibit a large 
array of phenotypes affecting different tissues and different developmental stages (for review, see Artavanis-Tsakonas et al. 1991; Campos-Ortega and Jan 1991). Thus, analysis of additional mutant Notch1 alleles may reveal other requirements for this gene during embryonic development in mice.

\section{Materials and methods}

\section{Targeting vector construction}

Isolation of a 17-kb genomic clone encoding part of the mouse Notch1 gene has been reported previously (Franco del Amo et al. 1992). A HindIII-NsiI fragment of this genomic clone was subcloned and used for targeting vector construction. Exons were located and exon-intron boundaries were determined by nucleotide sequencing with specific oligonucleotide primers and by restriction enzyme mapping. To construct the targeting vector, we utilized the neo expression cassette from PGKneobpa (Soriano et al. 1991). A blunt-ended XhoI fragment from PGKneobpa was blunt-end-ligated into a unique BstXI site located in exon B in Figure 1. A pMCI-HSVTK cassette (Mansour et al. 1988) was introduced for negative selection as a Xhol fragment into a XhoI site in the plasmid polylinker at the $5^{\prime}$ end of the Notch1 genomic fragment. The targeting vector contained $2.6 \mathrm{~kb}$ of homologous sequence $5^{\prime}$ and $1.1 \mathrm{~kb}$ of homologous sequence $3^{\prime}$ of the neo cassette (Fig. 1B).

\section{Electroporation, selection, and screening of ES cells}

CJ7 (Swiatek and Gridley 1993) and CJ9 (derived in the same experimental series as CJ7 cells; T. Gridley, unpubl.) ES cells at passage 3-4 were electroporated with $25 \mu \mathrm{g}$ of linearized targeting vector DNA using a Bio-Rad Gene Pulser (500 $\mu \mathrm{F}, 240 \mathrm{~V}$ ). The electroporated cells were then placed under selection and replica-plated as described (Swiatek and Gridley 1993). DNA for Southern analysis was prepared from colonies in the replica plates by the method of Laird et al. (1991). For screening for homologous recombinants, DNA samples were analyzed by PCR as described below.

\section{Screening of G418-resistant colonies}

The ES cell DNA samples were screened for homologous recombinants using PCR. Primers for the reaction were from the neo gene (5'-TCGCAGCGCATCGCCTTCTATCG-3') and from Notch1 genomic sequence downstream from the Nsil site (5'-GGCACTCAGGGCCGGTGAAGGATC-3'). The PCR mix consisted of $20 \mu \mathrm{l}$ of lysis buffer $(50 \mathrm{~mm} \mathrm{KCl}, 10 \mathrm{~mm}$ Tris- $\mathrm{HCl}$ at $\mathrm{pH} 8.3,2 \mathrm{mM} \mathrm{MgCl}_{2}, 0.45 \%$ NP-40, $0.45 \%$ Tween $20,60 \mu \mathrm{g} / \mathrm{ml}$ of proteinase $\mathrm{K}), 2 \mu \mathrm{l}$ of $10 \times$ PCR buffer $\left[166 \mathrm{~mm}\left(\mathrm{NH}_{4}\right)_{2} \mathrm{SO}_{4}\right.$, $670 \mathrm{~mm}$ Tris- $\mathrm{HCl}(\mathrm{pH} 8.8), 1 \mathrm{mg} / \mathrm{ml}$ of BSA], $200 \mu \mathrm{M}$ each dNTP, $200 \mathrm{ng}$ of each primer, and $2 \mathrm{U} / \mu \mathrm{l}$ of Taq polymerase (Cetus) in a final volume of $40 \mu \mathrm{l}$. Temperature cycling conditions were at $95^{\circ} \mathrm{C}$ for $30 \mathrm{sec}^{\circ} 65^{\circ} \mathrm{C}$ for $30 \mathrm{sec}^{\circ}$ and $72^{\circ} \mathrm{C}$ for $90 \mathrm{sec}$ for 40 cycles. PCR products were resolved on $1 \%$ agarose gels.

\section{Genotyping ES cell lines and mice by Southern analysis and PCR}

DNA was isolated from the mutant ES cell lines and tail biopsy samples using standard procedures (Sambrook et al. 1989). Embryos isolated at $8.5-11.5 \mathrm{dpc}$ were genotyped using yolk sac DNA. Yolk sacs were incubated under mineral oil in $20-40 \mu l$ of lysis buffer at $55^{\circ} \mathrm{C}$ overnight. The proteinase $\mathrm{K}$ was inactivated by heating the lysates at $94^{\circ} \mathrm{C}$ for $30 \mathrm{~min}$, and the lysates genotyped using PCR or Southern analysis. PCR primers for the wild-type Notch1 allele were 5'-TCTAACTGCTCCGAGGAGATCA-3', located in EGF repeat 30, and 5'-CAGGGGTTGGAGAGACATTCATTG-3', located in EGF repeat 33. PCR conditions were as described above. For Southern analysis, the yolk sac lysate or $10 \mu \mathrm{g}$ of the ES cell or tail DNA was digested with the restriction enzymes $N$ coI, SacI, or NcoI-NsiI. The DNA was fractionated on a $0.8 \%$ agarose gel, transferred to ZetaProbe GT membranes (Bio-Rad), and hybridized with probe A (Fig. 1B), a 1.7-kb BamHI genomic fragment. Hybridization and washing conditions were as described by the membrane supplier.

\section{Blastocyst injection and animal breeding}

ES cell colonies that screened positive for homologous recombination at the Notch1 locus were injected into blastocysts from C57Bl/6 mice as described (Swiatek and Gridley 1993). Male chimeras with extensive ES cell contribution to the coat were bred with C57Bl/6J females to test for germ-line transmission of the dominant agouti coat color marker. $F_{1}$ animals heterozygous for the Notch $1^{\text {in32 }}$ allele were intercrossed.

Breeding analysis with the Danforth's short tail (Sd) mutation

Male mice heterozygous for the $S d$ mutation on the RSV/Le inbred strain were obtained from the Jackson Laboratory (Bar Harbor, ME). These mice were also homozygous for $\operatorname{Re}(\operatorname{Rex})$, an unlinked dominant mutation causing curly whiskers and wavy fur. Genomic Southern blotting analysis revealed that there was a restriction-fragment-length polymorphism (RFLP) in the wildtype Notch1 gene between the allele carried by the RSV/Le mice and the allele carried by both $129 / \mathrm{Sv}$ and C57Bl/6J mice. Blotting of a SacI digest allowed the detection of both these wild-type alleles, as well as the Notch $1^{\text {in32 }}$ allele. The band sizes were Notch $1^{+}, \mathrm{RSV} / \mathrm{Le}, 7.0 \mathrm{~kb}$; Notch $1^{+}, 129 / \mathrm{Sv}$ and C57Bl/6J, $3.0 \mathrm{~kb}$; Notch $1^{\text {in } 32}, 2.4 \mathrm{~kb}$.

To assay complementation, male mice heterozygous for the $S d$ mutation were crossed to female mice heterozygous for the Notch $1^{\text {in } 32}$ mutation. The presence of the $S d$ mutation was determined visually by the presence of a very distinct, short stubby tail. Genotypes at the Notch1 locus were determined by Southern blotting, as described above. For the backcross analysis, short-tailed mice from the complementation cross were backcrossed to $\mathrm{C} 57 \mathrm{Bl} / 6$ mice, and genotypes of progeny were determined as above. Because of the RFLP in the wild-type Notch1 gene, short-tailed mice containing either the Notch $1^{\text {in } 32}$ allele or the Notch1 allele from the RSV strain could be backrossed informatively to $\mathrm{C} 57 \mathrm{Bl} / 6$ mice. Recombination frequency and standard error were calculated as described by Klein (1975).

\section{Morphological and histological analysis}

Embryos were dissected from the decidua and DNA was prepared from the yolk sacs for genotyping by PCR or by Southern blot analysis. Embryos were fixed overnight at $4^{\circ} \mathrm{C}$ in $4 \%$ paraformaldehyde in phosphate-buffered saline. Fixed embryos were dehydrated through graded alcohols, embedded in paraffin, sectioned at $6 \mu \mathrm{m}$, and stained with hematoxylin and eosin.

\section{Whole-mount immunohistochemistry}

Whole-mount immunohistochemistry with the monoclonal antibody $2 \mathrm{H} 3$, which recognizes a $155-\mathrm{kD}$ neurofilament protein [Dodd et al. 1988, obtained from the Developmental Studies 
Hybridoma Bank, maintained by the Department of Biology, University of Iowa, Iowa City, IA, under contract from the National Institute of Child Health and Development (NICHD)] was performed as described previously (Swiatek and Gridley 1993).

\section{Whole-mount in situ hybridization}

Whole-mount in situ hybridization was performed according to the method of Wilkinson (1992), with the following modifications. For $8.5 \mathrm{dpc}$ embryos the time of the proteinase $\mathrm{K}$ treatment was reduced to $7 \mathrm{~min}$. The time for preblocking the embryos with normal sheep serum was increased to $2.5 \mathrm{hr}$. In addition, to stop the histochemical reaction we found it necessary to store the embryos overnight in low $\mathrm{pH}$ phosphate-buffered saline (pH 5.5), 0.1\% Tween 20.

For Notch1, the probe for the whole-mount in situ hybridization experiments was the same probe used previously for in situ hybridization to sectioned embryos, the EcoRI-KpnI fragment of the Notch1 cDNA clone cl95 (Franco del Amo et al. 1992). For Notch2, the antisense riboprobe was transcribed from a 2462-bp fragment of the rat Notch2 cDNA extending from nucleotide 3991-6453 (Weinmaster et al. 1992). For flk-1, the antisense riboprobe was transcribed from a 710-bp fragment of the mouse flk-1 cDNA (Matthews et al. 1991) extending from nucleotide 301-1010, that was made by reverse transcriptase (RT) PCR (gift of Tom Sato, Roche Institute).

\section{Acknowledgments}

We thank Tom Sato for the flk-1 in situ hybridization probe.

The publication costs of this article were defrayed in part by payment of page charges. This article must therefore be hereby marked "advertisement" in accordance with 18 USC section 1734 solely to indicate this fact.

\section{References}

Andrews, B.J. and I. Herskowitz. 1989. The yeast SWI4 protein contains a motif present in developmental regulators and is part of a complex involved in cell-cycle-dependent transcription. Nature 342: 830-833.

Artavanis-Tsakonas, S., C. Delidakis, and R.G. Fehon. 1991. The Notch locus and the cell biology of neuroblast segregation. Annu. Rev. Cell Biol. 7: 427-452.

Aves, S.J., B.W. Durkacz, A. Carr, and P. Nurse. 1985. Cloning, sequencing, and transcriptional control of the Schizosaccharomyces pombe cdc10 start gene. EMBO I. 4: 457-463.

Bovolenta, P. and J. Dodd. 1991. Perturbation of neuronal differentiation and axon guidance in the spinal cord of mouse embryos lacking a floor plate: Analysis of Danforth's shorttail mutation. Development 113: 625-639.

Breeden, L. and K. Nasmyth. 1987. Similarity between cell-cycle genes of budding yeast and fission yeast and the Notch gene of Drosophila. Nature 329: 651-654.

Campos-Ortega, J.A. and Y.N. Jan. 1991. Genetic and molecular bases of neurogenesis in Drosophila melanogaster. Annu. Rev. Neurosci. 14: 399-420.

Charron, J., B.A. Malynn, P. Fisher, V. Stewart, L. Jeannotte, S.P. Goff, E.J. Robertson, and F.W. Alt. 1992. Embryonic lethality in mice homozygous for a targeted disruption of the N-myc gene. Genes \& Dev. 6: 2248-2257.

Chisaka, O., T.S. Musci, and M.R. Capecchi. 1992. Developmental defects of the ear, cranial nerves and hindbrain resulting from targeted disruption of the mouse homeobox gene Hox-1.6. Nature 355: 516-520.

Clarke, L.L., B.R. Grubb, S.E. Gabriel, O. Smiithies, B.H. Koller, and R.C. Boucher. 1992. Defective epithelial chloride transport in a gene-targeted mouse model of cystic fibrosis. Science 257: 1125-1128.

Coffman, C., W. Harris, and C. Kintner. 1990. Xotch, the Xenopus homolog of Drosophila Notch. Science 249: 1438-1441.

Coffman, C.R., P. Skoglund, W.A. Harris, and C.R. Kintner. 1993. Expression of an extracellular deletion of Xotch diverts cell fate in Xenopus embryos. Cell 73: 659-671.

Corbin, V., A.M. Michelson, S.M. Abmayr, V. Neel, E. Alcamo, T. Maniatis, and M.W. Young. 1991. A role for the Drosophila neurogenic genes in mesoderm differentiation. Cell 67: 311-323.

Danforth, C.H. 1930. Developmental anomalies in a strain of mice. Am. J. Anat. 45: 113-118.

Davis, L.H. and V. Bennett. 1990. Mapping the binding sites of human erythrocyte ankyrin for the anion exchanger and spectrin. J. Biol. Chem. 265: 10589-10596.

Dodd, J., S.B. Morton, D. Karagogeos, M. Yamamoto, and T. Jessell. 1988. Spatial regulation of axonal glycoprotein expression on subsets of embryonic spinal neurons. Neuron 1: 105-116.

Dorin, J.R., P. Dickinson, E.W. Alton, S.N. Smith, D.M. Geddes, B.J. Stevenson, W.L. Kimber, S. Fleming, A.R. Clarke, M.L. Hooper, L. Anderson, R.S. Beddington, and D.J. Porteous. 1992. Cystic fibrosis in the mouse by targeted insertional mutagenesis. Nature 359: 211-215.

Dunn, L.C., S. Gluecksohn-Schoenheimer, and V. Bryson. 1940. A new mutation in the mouse affecting spinal column and urogenital system. J. Hered. 31: 343-348.

Ellisen, L.W., J. Bird, D.C. West, A.L. Soreng, T.C. Reynolds, S.D. Smith, and J. Sklar. 1991. TAN-1, the human homolog of the Drosophila Notch gene, is broken by chromosomal translocations in T lymphoblastic neoplasms. Cell 66: 649661.

Ferguson, E.L. and H.R. Horvitz. 1989. The multivulva phenotype of certain Caenorhabditis elegans mutants results from defects in two functionally redundant pathways. Genetics 123: $109-121$.

Fitzgerald, K., H.A. Wilkinson, and I. Greenwald. 1993. $g l p-1$ can substitute for lin-12 in specifying cell fate decisions in $C$. elegans. Development 119: 1019-1027.

Fortini, M.E. and S. Artavanis-Tsakonas. 1993. Notch: Neurogenesis is only part of the picture. Cell 75: 1245-1247.

Fortini, M.E., I. Rebay, L.A. Caron, and S. Artavanis-Tsakonas. 1993. An activated Notch receptor blocks cell-fate commitment in the developing Drosophila eye. Nature 365: 555557.

Foster, G.G. 1975. Negative complementation at the Notch locus of Drosophila melanogaster. Genetics 81: 99-120.

Franco del Amo, F., D.E. Smith, P.J. Swiatek, M. GendronMaguire, R.J. Greenspan, A.P. McMahon, and T. Gridley. 1992. Expression of Motch, a mouse homolog of Drosophila Notch, suggests an important role in early postimplantation mouse development. Development 115: 737-745.

Franco del Amo, F., M. Gendron-Maguire, P.J. Swiatek, N.A. Jenkins, N.G. Copeland, and T. Gridley. 1993. Cloning, analysis and chromosomal localization of Notch-1, a mouse homolog of Drosophila Notch. Genomics 15: 259-264.

Gluecksohn-Schoenheimer, S. 1944. The development of normal and homozygous Brachy (T/T) mouse embryos in the extraembryonic coelom of the chick. Proc. Natl. Acad. Sci. 30: $134-140$.

Greenspan, R.J. 1990. The Notch gene, adhesion, and developmental fate in the Drosophila embryo. New Biol. 2: 595- 
600.

Greenwald, I. and G.M. Rubin. 1992. Making a difference: The role of cell-cell interactions in establishing separate identities for equivalent cells. Cell 68: 271-281.

Gridley, T. 1991. Insertional versus targeted mutagenesis in mice. New Biol. 3: 1025-1034.

Grimwade, B.G., M.A.T. Muskavitch, W.J. Welshons, B. Yedvobnick, and S. Artavanis-Tsakonas. 1985. The molecular genetics of the Notch locus in Drosophila melanogaster. Dev. Biol. 107: 503-519.

Grüneberg, H. 1953. Genetical studies on the skeleton of the mouse VI. Danforth's short tail. J. Genet. 51: 317-326.

. 1958. Genetical studies on the skeleton of the mouse XXII. The development of Danforth's short tail. I. Embryol. Exp. Morphol. 6: 124-148.

Hartenstein, A.Y., A. Rugendorff, U. Tepass, and V. Hartenstein. 1992. The function of the neurogenic genes during epithelial development in the Drosophila embryo. Development 116: 1203-1220.

Thappan, C., D. Gallahan, C. Stahle, E. Chu, G.H. Smith, G. Merlino, and R. Callahan. 1992. Expression of an activated Notch-related int-3 transgene interferes with cell differentiation and induces neoplastic transformation in mammary and salivary glands. Genes \& Dev. 6: 345-355.

Kataoka, T., S. Powers, C. McGill, O. Fasano, J. Strathern, J. Broach, and M. Wigler. 1984. Genetic analysis of yeast RASl and RAS2 genes. Cell 37: 437-445.

Kaufman, M.H. 1992. The atlas of mouse development. Academic Press, New York.

Kidd, S., M.R. Kelley, and M.W. Young. 1986. Sequence of the Notch locus of Drosophila melanogaster: Relationship of the encoded protein to mammalian clotting and growth factors. Mol. Cell. Biol. 6: 3094-3108.

Kidd, S., T.J. Lockett, and M.W. Young. 1983. The Notch locus of Drosophila melanogaster. Cell 34: 421-433.

Klein, J. 1975. Principles of genetic analysis. In Biology of the mouse histocompatibility-2 complex. pp. 181-191. SpringerVerlag, Berlin, Germany.

Kopan, R. and H. Weintraub. 1993. Mouse Notch: Expression in hair follicles correlates with cell fate determination. I. Cell Biol. 121: 631-641.

Laird, P.W., A. Zijderveld, K. Linders, M.A. Rudnicki, R. Jaenisch, and A. Berns. 1991. Simplified mammalian DNA isolation procedure. Nucleic Acids Res. 19: 4293.

Lambie, E.J. and J. Kimble. 1991. Two homologous regulatory genes, lin-12 and $g l p-1$, have overlapping functions. Development 112: 231-240.

Lardelli, M. and U. Lendahl. 1993. MotchA and MotchB-Two mouse Notch homologues coexpressed in a wide variety of tissues. Exp. Cell Res. 204: 364-372.

Lieber, T., S. Kidd, E. Alcamo, V. Corbin, and M.W. Young. 1993. Antineurogenic phenotypes induced by truncated Notch proteins indicate a role in signal transduction and may point to a novel function for Notch in nuclei. Genes \& Dev. 7: 1949-1965.

Lufkin, T., A. Dierich, M. LeMeur, M. Mark, and P. Chambon. 1991. Disruption of the Hox-1.6 homeobox gene results in defects in a region corresponding to its rostral domain of expression. Cell 66: 1105-1119.

Lux, S.E., K.M. John, and V. Bennett. 1990. Analysis of cDNA for human erythrocyte ankyrin indicates a repeated structure with homology to tissue-differentiation and cell-cycle control proteins. Nature 344: 36-42.

Lyon, M.F. 1989. Rules and guidelines for gene nomenclature. In Genetic variants and strains of the laboratory mouse led. M.F. Lyon and A.G. Searlel, pp. 1-11. Oxford University
Press, Oxford, UK.

Lyon, M.F. and M.C. Kirby. 1993. Mouse chromosome atlas. Mouse Genome 91: 40-80.

Mallo, M., F. Franco del Amo, and T. Gridley. 1993. Cloning and developmental expression of $\mathrm{Grg}$, a mouse gene related to the groucho transcript of the Drosophila Enhancer of split complex. Mech. Dev. 42: 67-76.

Mango, S.E., E.M. Maine, and J. Kimble. 1991. Carboxy-terminal truncation activates $g l p-1$ protein to specify vulval fates in Caenorhabditis elegans. Nature 352: 811-815.

Mansour, S.L., K.R. Thomas, and M.R. Capecchi. 1988. Disruption of the proto-oncogene int-2 in mouse embryo-derived stem cells: A general strategy for targeting mutations to nonselectable genes. Nature 336: 348-352.

Matthews, W., C.T. Jordan, M. Gavin, N.A. Jenkins, N.G. Copeland, and I.R. Lemischka. 1991. A receptor tyrosine kinase cDNA isolated from a population of enriched primitive hematopoietic cells and exhibiting close genetic linkage to c-kit. Proc. Natl. Acad. Sci. 88: 9026-9030.

McMahon, A.P., A.L. Joyner, A. Bradley, and J.A. McMahon. 1992. The midbrain-hindbrain phenotype of $W n t-1^{-} / W n t-$ $1^{-}$mice results from stepwise deletion of engrailed-expressing cells by 9.5 days postcoitum. Cell 69: 581-595.

Moens, C.B., A.B. Auerbach, R.A. Conlon, A.L. Joyner, and J. Rossant. 1992. A targeted mutation reveals a role for $\mathrm{N}-m y c$ in branching morphogenesis in The embryonic mouse lung. Genes \& Dev. 6: 691-704.

Moens, C.B., B.R. Stanton, L.F. Parada, and J. Rossant. 1993. Defects in heart and lung development in compound heterozygotes for two different targeted mutations at the N-myc locus. Development 119: 485-499.

Ohno, H., G. Takimoto, and T.W. McKeithan. 1990. The candidate proto-oncogene $b c l-3$ is related to genes implicated in cell lineage determination and cell cycle control. Cell 60: $991-997$.

Portin, P. 1975. Allelic negative complementation at the Abruptex locus of Drosophila melanogaster. Genetics 81: 121133.

Reaume, A.G., R.A. Conlon, R. Zirngibl, T.P. Yamaguchi, and J. Rossant. 1992. Expression analysis of a Notch homologue in the mouse embryo. Dev. Biol. 154: 377-387.

Rebay, I., R.G. Fehon, and S. Artavanis-Tsakonas. 1993. Specific truncations of Drosophila Notch define dominant activated and dominant negative forms of the receptor. Cell 74: 319329.

Robbins, J., B.J. Blondel, D. Gallahan, and R. Callahan. 1992. Mouse mammary tumor gene int-3: A member of the notch gene family transforms mammary epithelial cells. $J$. Virol. 66: 2594-2599.

Roehl, H. and J. Kimble. 1993. Control of cell fate in C. elegans by a GLP-1 peptide consisting primarily of ankyrin repeats. Nature 364: 632-635.

Rudnicki, M.A., P.N.J. Schnegelsberg, R.H. Stead, T. Braun, H.H. Arnold, and R. Jaenisch. 1993. MyoD or Myf-5 is required for the formation of skeletal muscle. Cell 75: 1351-1359.

Rugh, R. 1990. The mouse: Its reproduction and development. Oxford University Press, Oxford, UK.

Sambrook, J., E.F. Fritsch, and T. Maniatis. 1989. Molecular cloning: A laboratory manual. Cold Spring Harbor Laboratory Press, Cold Spring Harbor, New York.

Sasai, Y., R. Kageyama, Y. Tagawa, R. Shigemoto, and S. Nakanishi. 1992. Two mammalian helix-loop-helix factors structurally related to Drosophila hairy and Enhancer of split. Genes \& Dev. 6: 2620-2634.

Snell, G.D. and L.C. Stevens. 1966. Early embryology. In Biology of the laboratory mouse (ed. E.L. Green), pp. 205-245. 
Dover Press, New York.

Snouwaert, J.N., K.K. Brigman, A.M. Latour, N.N. Malouf, R.C. Boucher, O. Smithies, and B.H. Koller. 1992. An animal model for cystic fibrosis made by gene targeting. Science 257: 1083-1088.

Soriano, P., C. Montgomery, R. Geske, and A. Bradley. 1991. Targeted disruption of the c-src proto-oncogene leads to osteopetrosis in mice. Cell 64: 693-702.

Spence, A.M., A. Coulson, and J. Hodkin. 1990. The product of fem-1, a nematode sex-determining gene, contains a motif found in cell cycle control proteins and receptors for cell-cell interactions. Cell 60: 981-990.

Stanton, B.R., A.S. Perkins, L. Tessarollo, D.A. Sassoon, and L.F. Parada. 1992. Loss of $\mathrm{N}-m y c$ function results in embryonic lethality and failure of the epithelial component of the embryo to develop. Genes \& Dev. 6: 2235-2247.

Sternberg, P.W. 1993. Falling off the knife edge. Curr. Biol. 3: 763-765.

Stifani, S., C.M. Blaumeller, N.J. Redhead, R.E. Hill, and S. Artavanis-Tsakonas. 1992. Human homologs of a Drosophila Enhancer of Split gene product define a novel family of nuclear proteins. Nature Genet. 2: 119-127.

Struhl, G., K. Fitzgerald, and I. Greenwald. 1993. Intrinsic activity of the Lin-12 and Notch intracellular domains in vivo. Cell 74: 331-345.

Swiatek, P. and T. Gridley. 1993. Perinatal lethality and defects in hindbrain development in mice homozygous for a targeted mutation of the zinc finger gene Krox20. Genes \& Dev. 7: 2071-2084.

Theiler, K. 1959. Anatomy and development of the "truncate" (boneless) mutation in the mouse. Am. J. Anat. 104: 319343.

- 1989. The house mouse: Atlas of embryonic development. Springer Verlag, New York.

Thomas, J.H. 1993. Thinking about genetic redundancy. Trends Genet. 9: 395-399.

Thompson, C.C., T.A. Brown, and S.L. McKnight. 1991. Convergence of Ets- and Notch-related structural motifs in a heteromeric DNA binding complex. Science 253: 762-768.

Weinmaster, G., V.J. Roberts, and G. Lemke. 1991. A homolog of Drosophila Notch expressed during mammalian development. Development 113: 199-205.

- 1992. Notch2: A second mammalian Notch gene. Development 116: 931-941.

Welshons, W.J. 1971. Genetic basis for two types of recessive lethality at the Notch locus of Drosophila. Genetics 68: $259-268$.

Wharton, K.A., K.M. Johansen, T. Xu, and S. Artavanis-Tsakonas. 1985. Nucleotide sequence from the neurogenic locus Notch implies a gene product that shares homology with proteins containing EGF-like repeats. Cell 43: 567-581.

Wilkinson, D.G. 1992. Whole mount in situ hybridization of vertebrate embryos. In In situ hybridization: A practical approach (ed. D.G. Wilkinson), pp. 75-83. IRL Press, Oxford, UK.

Yamaguchi, T.P., D.J. Dumont, R.A. Conlon, M.L. Breitman, and J. Rossant. 1993. flk-1, an flt-related receptor tyrosine kinase is an early marker for endothelial cell precursors. $D e$ velopment 118: 489-498.

Yochem, J. and I. Greenwald. 1989. glp-1 and lin-12, genes implicated in distinct cell-cell interactions in C. elegans, encode similar transmembrane proteins. Cell 58: 553-563. 


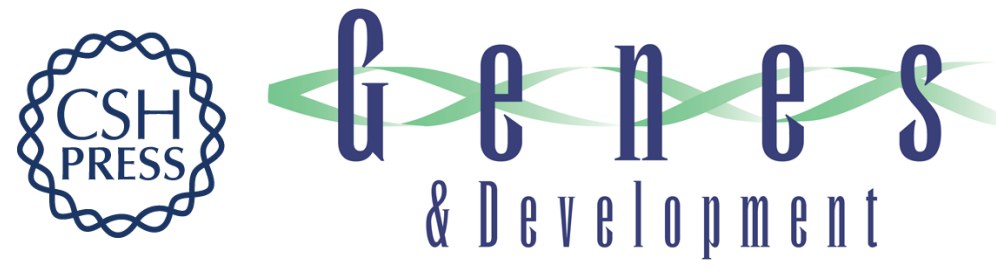

\section{Notch1 is essential for postimplantation development in mice.}

P J Swiatek, C E Lindsell, F F del Amo, et al.

Genes Dev. 1994, 8:

Access the most recent version at doi:10.1101/gad.8.6.707

References This article cites 77 articles, 30 of which can be accessed free at:

http://genesdev.cshlp.org/content/8/6/707.full.html\#ref-list-1

License

Email Alerting Receive free email alerts when new articles cite this article - sign up in the box at the top Service right corner of the article or click here.

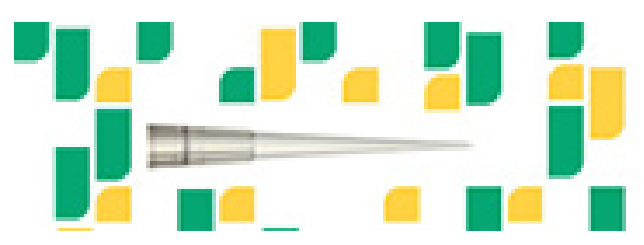

Focused on your science. 